\title{
EFFECTS OF CADMIUM AND NICKEL EXPOSURE ON HAEMATOLOGICAL PARAMETERS OF COMMON CARP, CYPRINUS CARPIO L.
}

\author{
Ewa BRUCKA-JASTRZĘBSKA ${ }^{1 *}$, Mikołaj PROTASOWICKI ${ }^{2}$ \\ ${ }^{1}$ Division and Chair of Physiology, University of Szczecin, Poland \\ ${ }^{2}$ Division and Chair of Toxicology, Agricultural University of Szczecin, Poland
}

Brucka-Jastrzębska E., Protasowicki M., 2005. Effects of cadmium and nickel exposure on haematological parameters of common carp, Cyprinus carpio L. Acta Ichthyol. Piscat. 35 (1): 29-38.

\begin{abstract}
Introduction. Single intraperitoneal injections of sublethal doses of cadmium (10 $\mu \mathrm{g} \mathrm{Cd} \cdot \mathrm{kg}^{-1}$ body weight) and nickel (60 $\mu \mathrm{g} \mathrm{Cd} \cdot \mathrm{kg}^{-1}$ body weight) were administered to carp, Cyprinus carpio L., to determine detoxification potential of the fish affected after transfer to a clean milieu, as revealed by haematological parameters. Observation of haematological parameters allows the most rapid detection of changes in fish after cadmium and nickel injection. Disrupted haematological patterns appear very quickly and precede changes in fish behaviour and visible lesions. The rapidity of toxic effects exerted by xenobiotics is related to the blood's transport function, with the blood distributing the metals to all the body parts.

Materials and methods. Each experiment took 60 days and was divided into 8 stages during which blood was collected for assays. At each stage, blood samples were assayed for selected haematological parameters (RBC, WBC, Hb, Hct, MCV, MCHC, MCH).

Results. Cadmium and nickel exposure-related changes in haematological parameters were detected. Immediately after injection, the haematological parameters were seen to change, a return to the normal values being observed after some time. The study allowed following the changes in the haematological parameters of cadmium- and nickel-injected carp during the process of detoxification.

Conclusions. Within the 60 days following injection of sublethal doses of cadmium and nickel, haematological parameters were observed to revert to the levels close to those in the control.
\end{abstract}

Key words: toxicity, fish, Cyprinus carpio, cadmium, nickel, RBC, WBC, Hb, Hct, leukogram, erythrocyte-related parameters

\section{INTRODUCTION}

The variety of human activities acting upon the natural environment result in the release of different chemicals, including heavy metals such as cadmium and nickel. When in excess, the metals adversely affect the habitats and organisms they support. Chemical changes disturb the equilibrium (homeostasis) of ecosystems and thus prevent their normal functioning. In polluted water bodies, concentrations of compounds containing both essential metals (nickel) and those playing no part in an organism's functioning (cadmium) may increase to toxic levels (Jezierska and Witeska 2001). The above affect individual development of plants and animals. Biological effects of disturbed chemical equilibrium in the habitat appear early, before individual organisms show symptoms and biochemical changes.

Environmental pollution and the resultant changes are related to constant matter flow and exchange. The fish are intimately associated with water and constitute an important food item in human diet. For this reason, they may be one of the sources of xenobiotics for humans; xenobiotics being substances that adversely affect life functions. Observation of haematological parameters allows the most rapid detection of changes in fish. Disrupted haematological patterns appear very quickly and precede changes in fish behaviour and visible lesions. The rapidity of toxic effects, exerted by heavy metals, is related to the blood's transport function, with the blood distributing the metals to all the body parts. Evaluation of toxic effects of the metals is facilitated by results of the basic haematological assays (RBC, WBC, $\mathrm{Hb}$, Hct, leukocyte and erythrocyte appearance).

The research described in this paper was aimed at following effects of cadmium and nickel exposure in the body of common carp, Cyprinus carpio L., based on changes in haematological parameters after intraperitoneal injections. Specifically, the dynamics of haematological parameters after single intraperitoneal injections of cadmium and nickel compounds were followed and are described in detail. The doses of toxic substance, admin-

\footnotetext{
${ }^{*}$ Correspondence: Dr Ewa Brucka-Jastrzębska, Katedra Fizjologii, Uniwersytet Szczeciński, Al. Piastów 40b, 71-065 Szczecin, Poland, e-mail: eva99@ op.pl
} 
istered through intraperitoneal, injection were adjusted individually to the weight of each fish individual.

\section{MATERIALS AND METHODS}

The study involved carp, Cyprinus carpio L., obtained from the field experimental station of the Agricultural Universityof Szczecin. A total of 240 fish weighing 88.3-138.7 $\mathrm{g}$ and measuring 17.5-20.2 cm was used. At the onset of the experiment, the fish were 3 months old, while at termination, they were 5.5 months old. After delivery to the laboratory, the fish were placed in aerated 120-1 tanks filled with dechlorinated tap water for a 14-day acclimation period, during which time water in the tanks was changed daily. During acclimation, the carp were in good condition. During the experiment, the fish were fed Aller Aqua pelleted feed containing $37 \%$ protein and $12 \%$ lipids, the food being identical to that used in the field experimental station's culture. The daily feed ration was $3.4 \pm 0.2 \mathrm{~g}$ per fish. During the experiment, the tank water temperature, dissolved oxygen content, $\mathrm{pH}$, and hardness amounted to or ranged within $21 \pm 2^{\circ} \mathrm{C}, 8.0-9.0 \mathrm{mg}$ $\mathrm{O}_{2} \cdot 1-1,7.0-7.5$, and $10.71 \mathrm{mval} \cdot \mathrm{l}^{-1}$, respectively.

In two parallel treatments, the fish were subjected to single intraperitoneal injections of cadmium and nickel.

Prior to injections, the fish were randomly assigned to 3 groups. The first group, serving as a control $\left(\mathrm{W}_{\text {cont. }}\right)$, consisted of fish that were not subjected to any treatment. The fish in the second group $\left(\mathrm{W}_{C d}\right)$ were subjected to a single intraperitoneal injection of aqueous solution of cadmium $\left(\mathrm{Cd}^{2+}\right)$ in the form of cadmium (II) nitrate (V) at a dose of $10 \mu \mathrm{g} \cdot \mathrm{kg}^{-1}$ body weight. The fish in the third group $\left(\mathrm{W}_{N i}\right)$ received an intraperitoneal injection of aqueous solution of nickel $\left(\mathrm{Ni}^{2+}\right)$ in the form of nickel (II) nitrate (V) at a dose of $60 \mu \mathrm{g} \cdot \mathrm{kg}^{-1}$ body weight.

Every experiment fish became, weighed, and passed to intraperitoneal dose became closely enumerated onto definite mass of body. Each fish was treated as an individual but the final results show mean values. Every fish independently from weight received $1 \mu \mathrm{l}$ solution in which xenobiotics were dissolved.

Carp, which made up additional experimental group received intraperitoneal injection of $1 \mu \mathrm{l}$ of deionised water. The results will be published as a separate paper.

The experiment continued for 60 days following the injections. The aqueous solutions of cadmium and nickel injected were prepared with deionised UV-sterilised water, produced by a Barnstead EASY pure UV apparatus. The individuals from each group were picked at random for assaying, before injection (hour 0), after 6 hours and after 1 , $3,7,14,30$, and 60 days. For the assays, at the times indicated above, the blood was drawn from the pericardium with a heparin-covered needle. The blood samples were transferred to $1.5-\mu \mathrm{l}$ vials covered with $500 \mathrm{Li}$ heparin (Sarstedt).

The following haematological assays were performed:

1) Erythrocyte count (RBC) in $1 \mu \mathrm{l}$ of blood: the red blood cells were counted in the Bürker chamber, following $200 \times$ dilution in the Hayem fluid (Svobodová et al. 1986).
2) Leukocyte count (WBC) in $1 \mu$ l blood: the white blood cells were counted in the Bürker chamber, following $200 \times$ dilution in the Türk fluid (Bomski 1995).

3) Haemoglobin content $(\mathrm{Hb})$ : photocolorimetrically, using the cyanmethaemoglobin technique, with Drabkin reagent, at $540 \mathrm{~nm}$ (Bomski 1995).

4) Haematocrit (Hct): in heparin-covered microhaematocrit tubes, using haematocrit centrifuge and a standard reading device.

The assays listed above were performed with standard ANALAB reagents.

The following erythrocyte-related indices were calculated:

1) Mean haemoglobin content $(\mathrm{MCH})[\mathrm{pg}]$,

2) Mean cell haemoglobin content (MCHC) $\left[\mathrm{g} \cdot 1^{-1} ; \%\right]$,

3) Mean erythrocyte volume (MCV) $\left[\mathrm{fl} ; \mu^{3}\right]$.

Blood samples of each fish were used to prepare MayGrünwald- and Giemsa-stained smears to read the leukocyte pattern. Percentage contributions of individual leukocyte forms were calculated based on 200 cells examined (Sopińska 1985, Bomski 1995).

The data were subjected to statistical treatment using the STATISTICA 6.0 software. The normality of distribution was tested for with the Kolmogorov-Smirnov test and one- and multi-way analyses of variance (ANOVA, Scheffe test) were performed; the significance of differences was tested at the significance level $P=0.05$.

\section{RESULTS}

Following single injections of sublethal doses of cadmium and nickel, applied to the fish in two groups, changes in haematocrit and haemoglobin content as well as in erythrocyte and leukocyte counts were observed (Table 1).

Statistically significant differences were revealed in the haematocrit, erythrocyte and leukocyte counts, mean cell haemoglobin content, and mean erythrocyte volume. Between-groups differences in the remaining parameters $(\mathrm{Hb}, \mathrm{MCH})$ proved non-significant (Table 1).

Fig. 1 illustrates levels of erythrocyte and leukocyte counts as well as haemoglobin content and haematocrit in the control $\left(\mathrm{W}_{\text {cont. }}\right)$ and in the cadmium- $\left(\mathrm{W}_{C d}\right)$ and nickel $\left(\mathrm{W}_{N i}\right)$ exposed fish. After cadmium injection, increased leukocyte counts were observed on days 1, 3, and 7, followed by a reduction in that parameter. At the end of the experiment, the leukocyte count was similar in all groups. The erythrocyte system parameters ( $\mathrm{RBC}, \mathrm{Hb}, \mathrm{Hct}$ ) were constantly changing in time following the injection, as the fish-transferred to a non-toxic environment-were undergoing detoxification. On day 60, a return to the state of equilibrium was observed, whereby the values of individual parameters did not differ from those recorded in the control.

The erythrocyte count variations were reflected in the dynamics of the erythrocyte parameters $(\mathrm{MCH}, \mathrm{MCHC}$, $\mathrm{MCV}$ ) that provide information on the red blood cell physiology. Following cadmium administration, the fish affected showed changes in the mean haemoglobin content $(\mathrm{MCH})$ (Table 2). A reduction, lasting up to 1 day, was observed 6 hours after injection. Subsequently (between days 3 and 7), $\mathrm{MCH}$ was observed to increase, to decrease 
Haematological parameters of control and Cd- and Ni-injected carp

\begin{tabular}{|c|c|c|c|c|c|c|c|c|}
\hline \multirow[b]{2}{*}{ Parameter } & \multirow{2}{*}{$\begin{array}{c}\text { Unit } \\
\text { (SI units) }\end{array}$} & \multirow{2}{*}{$\begin{array}{l}\text { Fish } \\
\text { group* }\end{array}$} & \multicolumn{4}{|c|}{ Content } & \multicolumn{2}{|c|}{$\begin{array}{c}\text { Significance } \\
\text { of differences, } \\
P<0.05^{*}\end{array}$} \\
\hline & & & $\bar{x}$ & $\pm s$ & Min. & Max. & $\begin{array}{l}\text { Between } \\
\text { groups }\end{array}$ & $\begin{array}{l}\text { Within } \\
\text { group } \\
\text { (changes } \\
\text { in time) }\end{array}$ \\
\hline \multirow{3}{*}{$\mathrm{Hb}$} & \multirow{3}{*}{$\begin{array}{c}{\left[\mathrm{g} \cdot \mathrm{1}^{-1}\right]} \\
(\mathrm{g} \%)\end{array}$} & $\mathrm{W}_{\text {cont. }}$ & $\begin{array}{l}63.28 \\
(6.32)\end{array}$ & $\begin{array}{l}9.28 \\
(0.92)\end{array}$ & $\begin{array}{c}37.27 \\
(3.72)\end{array}$ & $\begin{array}{c}78.5 \\
(7.85)\end{array}$ & $\mathrm{a}$ & - \\
\hline & & $\mathrm{W}_{\mathrm{Cd}}$ & $\begin{array}{l}63.24 \\
(6.32)\end{array}$ & $\begin{array}{l}10.56 \\
(1.05)\end{array}$ & $\begin{array}{l}44.44 \\
(4.44)\end{array}$ & $\begin{array}{c}84.2 \\
(8.42)\end{array}$ & $\mathrm{a}$ & - \\
\hline & & $\mathrm{W}_{\mathrm{Ni}}$ & $\begin{array}{l}69.53 \\
(6.95)\end{array}$ & $\begin{array}{l}9.58 \\
(0.95)\end{array}$ & $\begin{array}{l}41.66 \\
(4.16)\end{array}$ & $\begin{array}{c}87.5 \\
(8.75) \\
\end{array}$ & $\mathrm{a}$ & + \\
\hline \multirow{3}{*}{ Hct } & \multirow{3}{*}{$\begin{array}{c}{\left[1 \cdot 1^{-1}\right]} \\
(\%)\end{array}$} & $\mathrm{W}_{\text {cont. }}$ & $\begin{array}{l}0.28 \\
(28)\end{array}$ & $\begin{array}{c}0.06 \\
(6)\end{array}$ & $\begin{array}{l}0.24 \\
(24)\end{array}$ & $\begin{array}{l}0.32 \\
(32)\end{array}$ & $\mathrm{a}$ & - \\
\hline & & $\mathrm{W}_{\mathrm{Cd}}$ & $\begin{array}{l}0.28 \\
(28)\end{array}$ & $\begin{array}{l}0.04 \\
(4)\end{array}$ & $\begin{array}{l}0.22 \\
(22)\end{array}$ & $\begin{array}{l}0.35 \\
(35)\end{array}$ & $\mathrm{a}$ & - \\
\hline & & $\mathrm{W}_{\mathrm{Ni}}$ & $\begin{array}{l}0.29 \\
(29) \\
\end{array}$ & $\begin{array}{c}0.03 \\
(3)\end{array}$ & $\begin{array}{l}0.24 \\
(24) \\
\end{array}$ & $\begin{array}{l}0.39 \\
(39) \\
\end{array}$ & $\mathrm{c}$ & + \\
\hline \multirow{3}{*}{$\mathrm{RBC}$} & \multirow{3}{*}{$\begin{array}{c}{\left[\mathrm{T} \cdot \mathrm{1}^{-1}\right]} \\
\left(10^{3} \cdot \mathrm{mm}^{3}\right)\end{array}$} & $\mathrm{W}_{\text {cont. }}$ & $\begin{array}{c}1.54 \\
(1.54)\end{array}$ & $\begin{array}{c}0.20 \\
(0.20)\end{array}$ & $\begin{array}{c}0.92 \\
(0.92)\end{array}$ & $\begin{array}{c}1.97 \\
(1.97)\end{array}$ & $\mathrm{a}$ & - \\
\hline & & $\mathrm{W}_{\mathrm{Cd}}$ & $\begin{array}{c}1.48 \\
(1.48)\end{array}$ & $\begin{array}{c}0.29 \\
(0.29)\end{array}$ & $\begin{array}{c}0.74 \\
(0.74)\end{array}$ & $\begin{array}{c}2.07 \\
(2.07)\end{array}$ & $\mathrm{a}$ & + \\
\hline & & $\mathrm{W}_{\mathrm{Ni}}$ & $\begin{array}{c}1.21 \\
(1.21)\end{array}$ & $\begin{array}{c}0.26 \\
(0.26)\end{array}$ & $\begin{array}{c}0.77 \\
(0.77) \\
\end{array}$ & $\begin{array}{c}1.68 \\
(1.68)\end{array}$ & $\mathrm{c}$ & + \\
\hline \multirow{3}{*}{ WBC } & \multirow{3}{*}{$\begin{array}{c}{\left[\mathrm{G} \cdot \mathrm{1}^{-1}\right]} \\
\left(10^{6} \cdot \mu \mathrm{l}\right)\end{array}$} & $\mathrm{W}_{\text {cont. }}$ & $\begin{array}{c}7.86 \\
(7860)\end{array}$ & $\begin{array}{c}1.50 \\
(1500)\end{array}$ & $\begin{array}{c}4.54 \\
(4540)\end{array}$ & $\begin{array}{c}11.30 \\
(1130)\end{array}$ & $\mathrm{a}$ & - \\
\hline & & $\mathrm{W}_{\mathrm{Cd}}$ & $\begin{array}{c}9.96 \\
(9960)\end{array}$ & $\begin{array}{c}3.06 \\
(3060)\end{array}$ & $\begin{array}{c}4.02 \\
(4020)\end{array}$ & $\begin{array}{c}12.99 \\
(1299)\end{array}$ & $\mathrm{c}$ & + \\
\hline & & $\mathrm{W}_{\mathrm{Ni}}$ & $\begin{array}{c}10.29 \\
(1029)\end{array}$ & $\begin{array}{c}2.82 \\
(2820)\end{array}$ & $\begin{array}{c}4.01 \\
(4010) \\
\end{array}$ & $\begin{array}{c}12.99 \\
(1299)\end{array}$ & $\mathrm{c}$ & + \\
\hline \multirow{3}{*}{$\mathrm{MCV}$} & \multirow{3}{*}{$\begin{array}{c}{[\mathrm{fl}]} \\
\left(\mu \mathrm{m}^{3}\right)\end{array}$} & $\mathrm{W}_{\text {cont. }}$ & $\begin{array}{c}186.9 \\
(186.9)\end{array}$ & $\begin{array}{c}33.6 \\
(33.6)\end{array}$ & $\begin{array}{c}127.9 \\
(127.9)\end{array}$ & $\begin{array}{c}304.8 \\
(304.8)\end{array}$ & $\mathrm{a}$ & - \\
\hline & & $\mathrm{W}_{\mathrm{Cd}}$ & $\begin{array}{c}199.3 \\
(199.3)\end{array}$ & $\begin{array}{l}49.5 \\
(49.5)\end{array}$ & $\begin{array}{c}139.3 \\
(139.3)\end{array}$ & $\begin{array}{c}381.0 \\
(381.0)\end{array}$ & $\mathrm{a}$ & - \\
\hline & & $\mathrm{W}_{\mathrm{Ni}}$ & $\begin{array}{c}259.3 \\
(259.3) \\
\end{array}$ & $\begin{array}{c}60.2 \\
(60.2) \\
\end{array}$ & $\begin{array}{c}173.7 \\
(173.7) \\
\end{array}$ & $\begin{array}{c}357.8 \\
(357.8) \\
\end{array}$ & $\mathrm{c}$ & + \\
\hline \multirow{3}{*}{$\mathrm{MCHC}$} & \multirow{3}{*}{$\begin{array}{c}{\left[\mathrm{g} \cdot \mathrm{1}^{-1}\right]} \\
(\%)\end{array}$} & $\mathrm{W}_{\text {cont. }}$ & $\begin{array}{l}0.22 \\
(22)\end{array}$ & $\begin{array}{l}0.03 \\
(3)\end{array}$ & $\begin{array}{l}0.13 \\
(13)\end{array}$ & $\begin{array}{l}0.28 \\
(28)\end{array}$ & $\mathrm{a}$ & + \\
\hline & & $\mathrm{W}_{\mathrm{Cd}}$ & $\begin{array}{l}0.23 \\
(23)\end{array}$ & $\begin{array}{l}0.05 \\
(5)\end{array}$ & $\begin{array}{l}0.15 \\
(15)\end{array}$ & $\begin{array}{l}0.34 \\
(34)\end{array}$ & $\mathrm{c}$ & - \\
\hline & & $\mathrm{W}_{\mathrm{Ni}}$ & $\begin{array}{l}0.23 \\
(23)\end{array}$ & $\begin{array}{c}0.04 \\
(4)\end{array}$ & $\begin{array}{l}0.15 \\
(15)\end{array}$ & $\begin{array}{l}0.32 \\
(32)\end{array}$ & $\mathrm{c}$ & + \\
\hline \multirow{3}{*}{$\mathrm{MCH}$} & \multirow{3}{*}{$\begin{array}{l}{[\mathrm{pg}]} \\
(\mathrm{pg})\end{array}$} & $\mathrm{W}_{\text {cont. }}$ & $\begin{array}{c}41.79 \\
(41.79)\end{array}$ & $\begin{array}{c}8.89 \\
(8.89)\end{array}$ & $\begin{array}{c}24.20 \\
(24.20)\end{array}$ & $\begin{array}{c}69.42 \\
(69.42)\end{array}$ & $\mathrm{a}$ & - \\
\hline & & $\mathrm{W}_{\mathrm{Cd}}$ & $\begin{array}{c}44.96 \\
(44.96)\end{array}$ & $\begin{array}{c}14.17 \\
(14.17)\end{array}$ & $\begin{array}{c}24.02 \\
(24.02)\end{array}$ & $\begin{array}{c}97.27 \\
(97.27)\end{array}$ & $\mathrm{a}$ & - \\
\hline & & $\mathrm{W}_{\mathrm{Ni}}$ & $\begin{array}{c}69.53 \\
(69.53) \\
\end{array}$ & $\begin{array}{c}9.58 \\
(9.58) \\
\end{array}$ & $\begin{array}{c}41.66 \\
(41.66) \\
\end{array}$ & $\begin{array}{c}87.54 \\
(87.54) \\
\end{array}$ & $\mathrm{a}$ & - \\
\hline
\end{tabular}

* groups denoted as described in text; $\bar{x}$, mean; s, standard deviation; number of individuals $\mathrm{N}=40$; letters mark similarity (a) or differences (b) between groups; "-", changes in time non-significant; "+" changes in time significant

again on day 14, to increase, and to decrease again to the tion in MCHC was recorded as early as 24 hours after value recorded in the control $\left(\mathrm{W}_{\text {cont. }}\right)$. Cadmium intoxica- injection, followed by the return to the state of equilibrium. tion resulted also in variations in the mean cell haemoglo- Subsequently, on days 30 and 60, MCHC increased again. bin content $(\mathrm{MCHC})$ during detoxification. A clear reduc- The mean erythrocyte volume (MCV) was observed to 

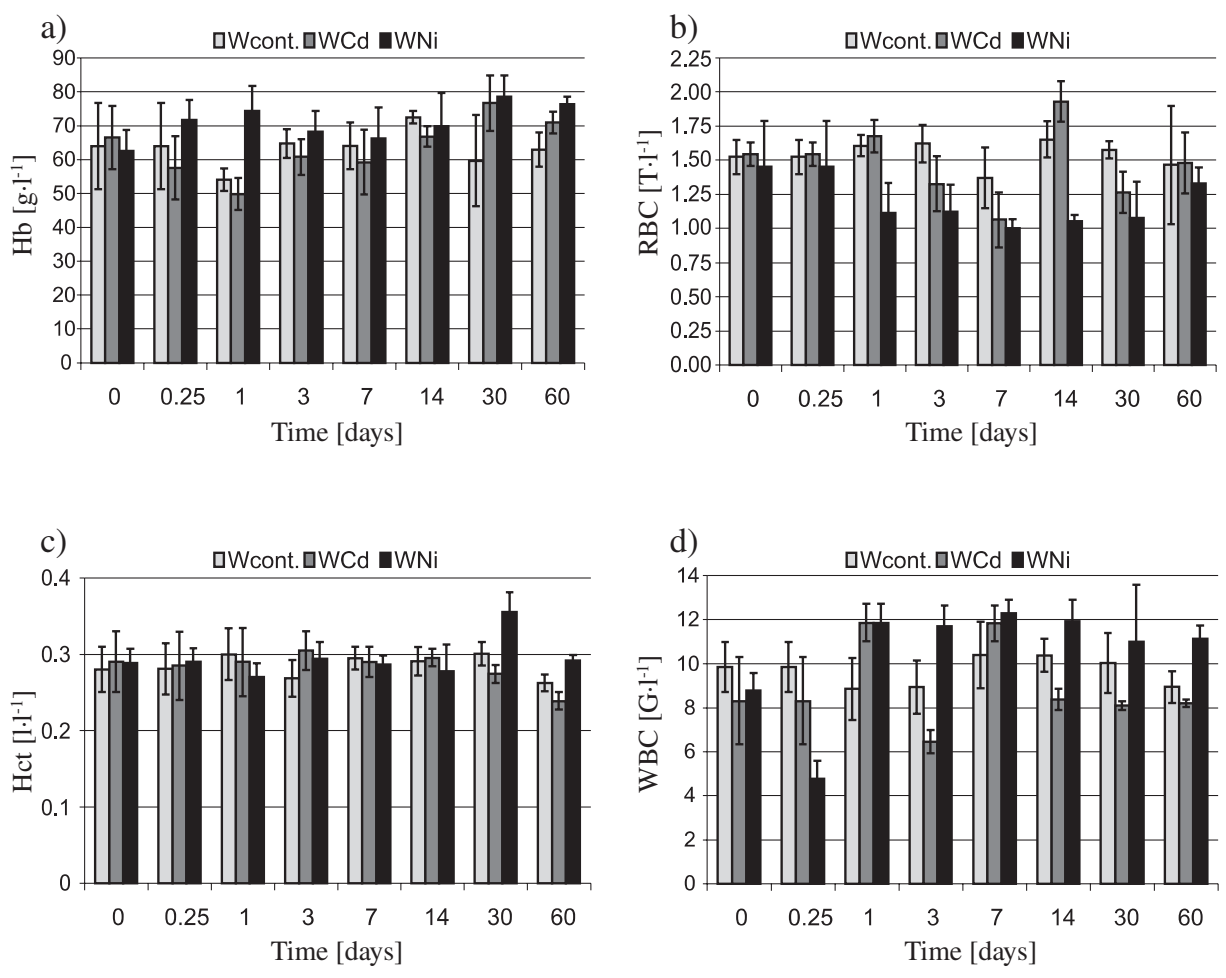

Fig. 1. Changes in haemoglobin content (a), erythrocyte (b), haematocrit (c) and leukocyte counts (d) in non-intoxicated and cadmium- and nickel-intoxicated carp during detoxification

markedly increase as late as on day 3 . The increase persisted until day 7 , to be followed by a reduction and the return to the equilibrium (homeostasis) level (Table 2).

Following nickel injection, all the haematological parameters (Hb, Hct, RBC, WBC, MCH, MCHC, MCV) were observed to undergo changes during detoxification (Fig. 1). The leukocyte count increased as early as 24 hours after injection, to drop to its control value $\left(\mathrm{W}_{\text {cont. }}\right)$ at the end of the experiment. The erythrocyte count in the nickel-exposed fish changed slightly only (Fig. 1b). Changes were also observed in the haemoglobin content (Fig. 1a) and haematocrit (Fig. 1c).

Changes in the erythrocyte-based indicators $(\mathrm{MCH}$, $\mathrm{MCHC}, \mathrm{MCV}$ ) were observed also following nickel injection (Table 2). An increased MCH was observed 24 hours after injection $\left(\mathrm{W}_{N i}\right)$, the increased level being maintained until day 3, on day 7, a rapid reduction of $\mathrm{MCH}$ occurred.

Subsequently, $\mathrm{MCH}$ increased again between day 14 and 30 to drop to the control level $\left(\mathrm{W}_{\text {cont. }}\right)$ on day 60 . An increased mean erythrocyte volume (MCV) was recorded on day 3 and did not return to the control level even after 60 days. MCHC increased from day 3 to day 60 and, a slight reduction beginning on termination of the experiment.

Table 3 summarises changes in the differential leukocyte count during the experiment. The blood smears showed a reduction in the percentage contributions of lymphocytes, small lymphocytes, and divided lymphocytes 6 hours after nickel injection, followed by the return to the state of equilibrium during the period of detoxification. The nickel-injected fish blood showed a reduced count of neutrophile granulocytes throughout the experiment; the number of rod-like, nuclei-containing granulo- cytes increased during day 1 and returned to the normal level thereafter. The counts of pseudobasophils and pseudoeosinophils decreased as early as 6 hours after nickel injection and subsequently stabilised. The smears revealed quantitative and qualitative changes in the appearance of leuko- and erythrocytes (Table 3). The smears permitted to observe the changes in erythro- and leukocytes, the changes being confirmed by differences in the percentage composition of both blood cell groups (Tables 1, 3). After 6 hours following cadmium injection, the total lymphocyte count was reduced, the reduction being caused mainly by the decrease in the small lymphocyte count, the percentage contribution of divided lymphocytes dropping after 1 day. Subsequently, during detoxification, the lymphocyte count was observed to return to the equilibrium level, the divided leukocyte count dropping again on day 60 . The neutrophile granulocyte count was reduced throughout the experiment, accompanied at first by an increased count of rod-like neutrophiles, which subsequently decreased and returned to the equilibrium level. The count of rod-like, nucleuscontaining granulocytes increased on day 1 to return to the equilibrium. The counts of pseudoeosinophils and monocytes increased as early as 6 hours after cadmium injection, the pseudobasophil count increasing after 1 day. Further on during the experiment, the counts reverted to the level shown by the control $\left(\mathrm{W}_{\text {cont. }}\right)$.

Cadmium and nickel injections resulted in a reduction of the erythrocyte count, as observed in the blood smears. The red blood cells were counted in the Bürker chamber. Erythrocyte haemolysis intensified, as evidenced by numerous erythrocyte shadows. Neutrophile granulocytes 


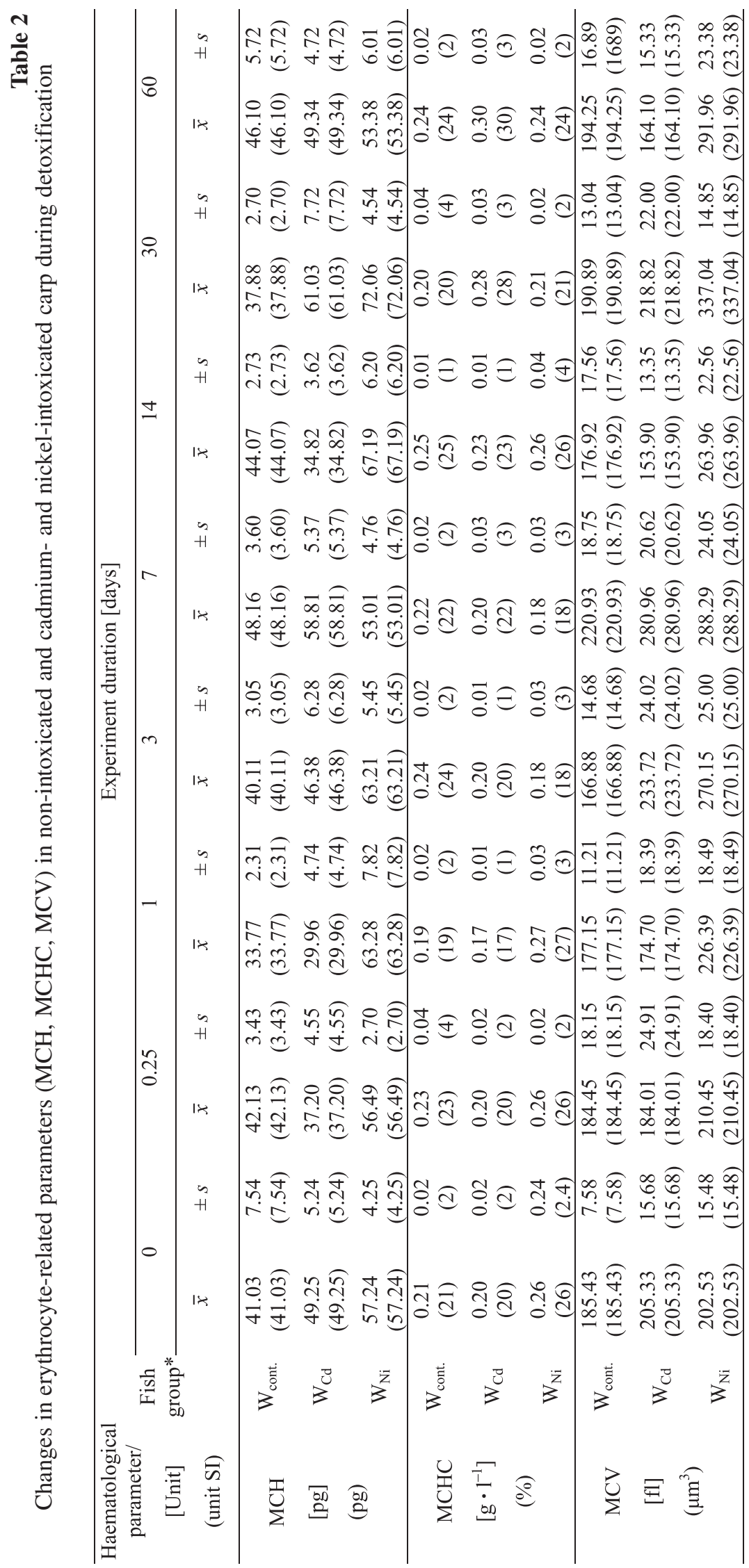




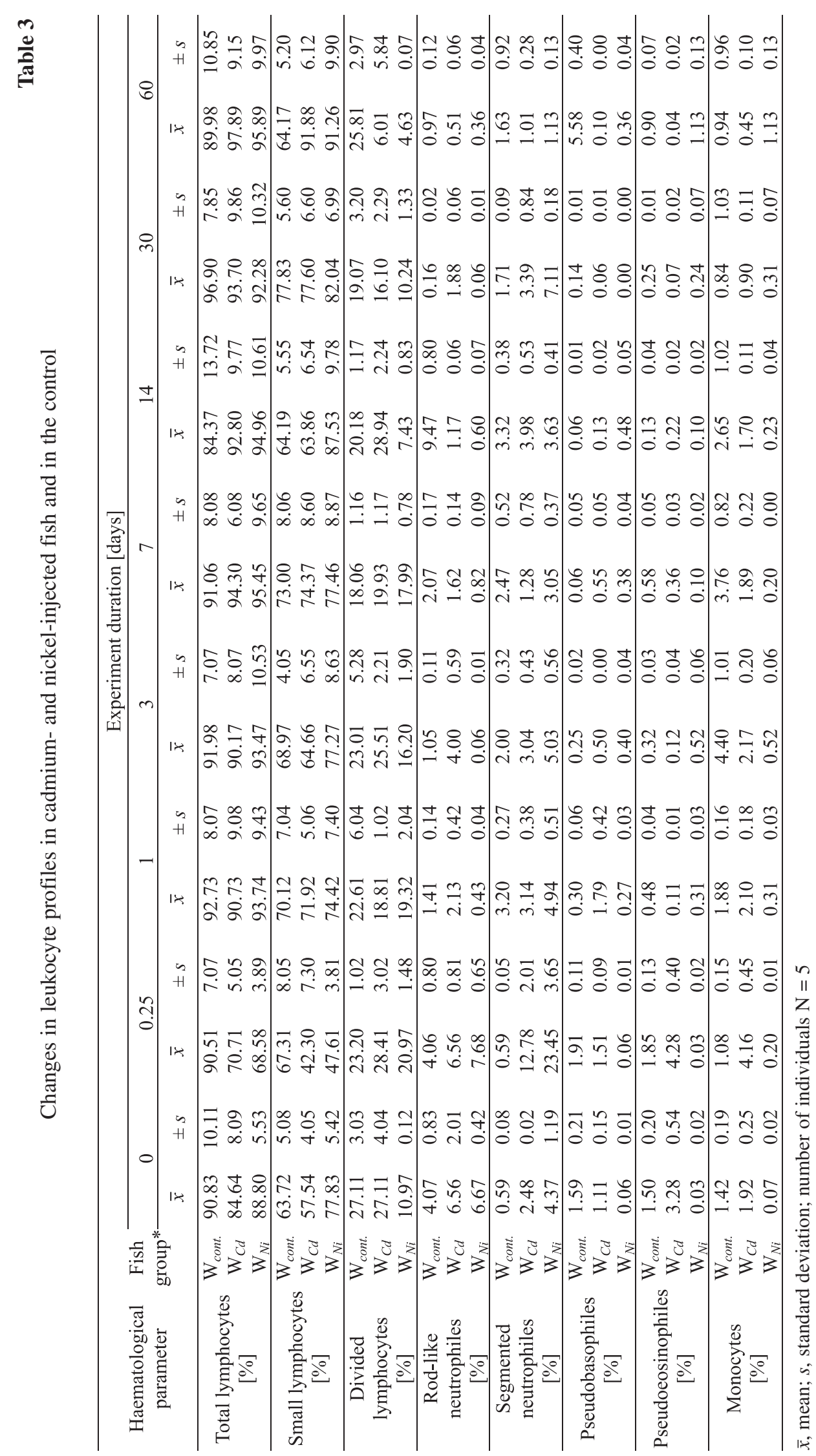


and monocytes featured vacuoles. The lymphocyte profile of all the experimental groups showed a marked reduction in segmented nucleus-containing neutrophile granulocytes. Significant differences were recorded in the counts of small and active lymphocytes, neutrophile and divided granulocytes, pseudobasophiles, pseudoeosinophiles, and monocytes (Table 3). Erythrocytes of the cadmium-injected fish tended to coin-roll. Those fish showed also a clear reduction in the erythrocyte count and differences in erythrocyte size (anisocytosis); the cell boundaries were blurred, surrounded by stain haloes.

Nickel injection resulted in a reduced monocyte count. As of day 7, the dividing erythrocyte count was observed to increase; the number of erythrocytes with cytoplasm bleached around the nucleus, a sign of disintegration, increased. The erythrocyte nuclear chromatin was observed to loosen up, evidencing the onset of erythrocyte haemolysis. The blood contained numerous shadows of disintegrating cells; the erythrocytes became surrounded by coloured haloes of decomposing cytoplasm. The leukocyte population features numerous blastic forms of the leukocyte developmental series, amounting to 1-3 per field of vision. The blood smears showed numerous young lymphocytes, active lymphocytes dominating over large ones; the presence of the first evidences of a response to a toxic compound. Vacuoles were observed to appear in neutrophile granulocytes and monocytes.

\section{DISCUSSION}

Biochemical damage is of paramount importance in cases of intoxication. It can be defined as a change or a biochemical defect that directly precedes a pathological change or a physiological disorder (Seńczuk 1999). Apart from the tissue targeted by a xenobiotic, there are also sites responsible for processes of absorption, metabolic detoxification, and excretion of xenobiotics. Additionally, toxicological diagnostics involves, e.g. haematological-, biochemical-, enzymatic assays and genetic analyses. All those analyses allow to, i.a. evaluate parameters of the compartment affected by toxic processes and facilitate comparisons with the control. They provide a basis on which to evaluate the structural changes in various parameters, e.g. haemoglobin level, haematocrit, and enzymes as well as disorders within genes (Pawelski and Maj 1987).

Vertebrates, including fish, have been for some time now the focus of toxicologists who carried out multi-faceted studies on toxic potential of various compounds, including metals, in relation to paths of their absorption into the body and duration of exposure. Important issues include changes in haematological parameters produced by toxic effects of various compounds, including salts of cadmium and nickel, because those parameters most readily, from the onset of exposure, reflect toxic effects. The present study provides a description of changes in haematological parameters of carp affected by cadmium and nickel during detoxification.

This paper discusses the dynamics of the fish blood's return to the state of internal homeostasis, based on the erythrocyte and leukocyte morphology. The experiments described were aimed at following effects of single injections of sublethal doses of cadmium and nickel. Cadmium was applied as a strongly toxic metal, its effects in animal systems being exclusively harmful, while nickel was regarded as an essential element when in trace amounts and toxic once a certain threshold dose is exceeded (Sobecka 2001).

Haematological parameters of fish are highly variable between and within species and seasons (Lusková 1997), with the values of individual indicators differing in relation to temperature, season, sex, food, and type of culture (Sopińska 1985, Thomas et al. 1999). Blood parameters may also show within-population differences (Allen 1993, Thomas et al. 1999), which explain wide variations within the control during the experiment described. Values of the haematological parameters recorded in the control were close to those typical of the healthy carp (Svobodová et al. 1994, 1997). Cadmium and nickel injections changed the carp haematology, with both qualitative and quantitative changes being observed. The exposure resulted in the erythrocyte system dysfunction, as evidenced by haemolytic anaemia, observed on the onset of the experiment and related to, i.a. rapid erythrocyte disintegration. Return to the state of homeostasis and levelling off of the haematological parameters were observed 14 or 30 days after injections.

Cadmium exposure resulted in increased haemolysis of the blood cells (erythrocytes and leucocytes) at the initial stage of the experiment. This was corroborated by the leukocyte and erythrocyte profiles obtained. Numerous (an average of 2-5 per field of vision) shadows of haemolysed erythrocytes, that had disintegrated as a result of cadmium exposure, appeared. When analysing data on the cadmiumexposed carp blood parameters, a significant reduction in erythrocytes after 7 days, an increase after 14 days, and a return to the normal level were observed. Cadmium injection produced changes in the erythrocyte size (microcytosis). Following nickel exposure, slight deviations from the control level were recorded in the erythrocyte count. The erythrocyte count reduction, reduced erythrocyte life span, and slower erythropoiesis were also reported from humans and animals exposed to various metals, including cadmium, lead, and nickel (Seńczuk 1999). However, the data collected during the experiment described showed nickel to be much less toxic than cadmium. An average of 1-2 dysmorphic erythrocytes per field of vision is evidence of a lower toxicity of the nickel salt applied, compared to that of cadmium. Erythrocyte swelling is related to intracellular osmotic disorders and stress. Erythrocyte haemolysis is associated with blood serum acidification and intracellular alkalisation (Nikinmaa and Huestis 1984).

Following cadmium and nickel exposure, the haemoglobin content $(\mathrm{Hb})$ and haematocrit $(\mathrm{Hct})$ showed variations in time, relative to the control. The $\mathrm{Hb}$ level decreased clearly after 7 days, the Hct level dropping 1 day after injection, to increase again as late as on day 30 as a result of cadmium exposure. Exposure to heavy metals leads to reduced haemoglobin content and haematocrit via disorders in haemopoietic processes and accelerated disintegration of erythrocyte cell membranes (Svobodová et al. 
1997). Cadmium shortens the erythrocyte life span and disturbs erythropoiesis (Haux and Larsson 1984, Houston and Keen 1984, Allen 1993). Application of cadmium resulted in changes in the leukocyte count (WBC), while after the nickel injection, a clear increase in that parameter was observed as early as after 24 hours. Cadmium in blood is bonded by erythrocytes, which become damaged in the process. That this was the case in the experiment described was evidenced by the markedly intensified erythrocyte disintegration during the first 3 days after injection and by RBC variations throughout. Witeska and Jezierska (1994, 1999) reported increased RBC and Hct in carp, following exposure to copper and lead. The carp kept in a $10 \mathrm{mg} \cdot \mathrm{l}^{-1}$ cadmium solution showed a reduction in Hct and an increase in RBC (Witeska and Jezierska 1994).

In this study, exposure to cadmium and nickel resulted in a reduction, followed by an increase, in $\mathrm{MCH}$. The $\mathrm{MCV}$ and MCHC levels changed after exposure, relative to the control, presumably as a result of a shortened erythrocyte life span immediately after injection and during metal redistribution. Morsy and Protasowicki (1990) demonstrated cadmium bioaccumulation to result in reductions in the erythrocyte count, haemoglobin content, and haematocrit, relative to the control. Those findings were corroborated during the initial stage of the experiment when anaemia was observed to set in; the condition leads to disorders in oxygen transport by the erythrocytes.

Differences in the granulocyte and lymphocyte counts between the control and the exposed fish are a result of a close relationship between those parameters and season and insolation (Sopińska 1985). The high level of lymphocytes observed in the leukogram was due to the fact that the fish younger that 5 months normally have a high lymphocyte level. A similar conclusion was drawn also by Buczek et al. (2000). A reduction in the erythrocyte count and the haemoglobin content accompanied by increased $\mathrm{MCH}$ and MCV were revealed by Reddy and Bashamohideen (1989) in carp exposed for 24 hours to cypermethrin $\left(0.02 \mathrm{mg} \cdot \mathrm{kg}^{-1}\right)$. Those authors compared their results to symptoms of hypochromic microcytic anaemia, accompanying iron deficiency in the body. In the presently reported study, the iron levels in kidney, liver, alimentary tract, skin, muscle, and gills levels were determined, and the results will be published as a separate paper.

Francis-Floyd (1992) suggested that microcytic anaemia usually occurs concurrently with haemolytic anaemia in fish. In the presently reported study, cadmium exposure resulted in an instantaneous reduction in iron content in the entire alimentary tract 6 hours after injection, the kidney iron content increasing 24 hour after exposure (Brucka-Jastrzębska and Protasowicki 2004). The cadmium-exposed fish showed a reduction in the mean haemoglobin content $(\mathrm{MCH}) 24$ hours after injection, whereas $\mathrm{MCH}$ increased after nickel injection. Cadmium exposure resulted in increased $\mathrm{MCV}$ and $\mathrm{MCHC}$, while nickel injection resulted in increased MCV only. The increased iron level after intoxication was most probably caused by disintegration of erythrocytes and the release of iron they contained (Sobecka 2001).
Similar changes were reported by Witeska (1998) from her study on cadmium effects on carp haematology. Sopińska (1985) found a slight increase in the erythrocyte count and a higher erythrocyte volume (MCV) in carp in summer, which is in agreement with the results of this work. The control fish showed a small increase in MCV, while all the erythrocyte-based parameters in the fish injected with both cadmium and nickel were much higher than those in the control. This was most probably related to the stress-related increase in the erythrocyte volume (Sopińska 1985). Palácková et al. (1992) observed reduced MCV in carp as a result of cadmium exposure.

The fish exposed to cadmium and nickel developed anaemia, most probably as a result of haemopoiesis being disturbed by the toxic substances and/or by the cellular membranes being damaged during acetylcholine hydrolysis by the erythrocyte cholinesterase. Increased iron levels in all the organs and tissues assayed were related to erythrocyte disintegration and the accompanying anaemia. Iron is released from erythrocytes, as they are haemolysed and is transported to other organs, including the liver and kidneys. Similar results were reported by Singh et al. (1992) who exposed Ictalurus punctatus to the pesticide propoxur at a concentration of $5 \mathrm{mg} \cdot \mathrm{l}^{-1}$, and by Areechon and Plumb (1990) who studied the species after a 96-hour exposure to malathion $\left(4.5 \mathrm{mg} \cdot \mathrm{l}^{-1}\right)$. The authors referred to suggested the xenobiotics to cause anaemia, the reduced leukocyte count being interpreted as a response to an increased ACTH level in reaction to stress produced by the presence of the toxicants. Cadmium effects on haemopoiesis may be related to the kidney haemopoietic tissue being damaged by cadmium affinity to kidneys (Saxena et al. 1992). A negative relationship between kidney cadmium content and erythrocyte count was reported by Ruparelia et al. (1990).

The rapid reduction in the lymphocyte count, observed 6 hours after injection, could have been most probably caused in part by stress-producing factors (injection, handling), in addition to toxic effects of cadmium and nickel.

According to Tomaszewski (1997), leukopenia may be an outcome of inhibited granulopoiesis or lymphopoiesis, resulting from primary or secondary changes in haemopoietic organs. Another cause can be sought in inhibited maturation of leukocytes and their release to the blood from tissue reserves or a stress response to toxic compounds. Srivastava and Sahai (1987) explained leukopenia as an organismic response to stress caused by toxic compounds. Those authors suggested that leukopenia and lymphopenia could be a part of the immune responses.

When examining the blood smears of the cadmium- and nickel-exposed fish in this study, changes in the leukocytes and erythrocytes were observed. Most conspicuous were numerous haemolytic changes of erythrocytes in both treatments. Cadmium injection was followed by the appearance of an increased number of blastic erythrocyte forms, while nickel exposure produced a similar effect among leukocytes. Cadmium administration produced an increase in the erythrocyte blastic forms (an average of 1-3 per field of vision). The highest number (an average of 5-8 per field of 
vision) of erythroblasts at different maturity stages emerged 7 days after cadmium injection, the number of blastic forms declining as the experiment proceeded. On the other hand, following nickel injection, the amount of erythroblasts remained at an identical level (an average of 0-1 per field of vision) throughout the experiment, with some changes presumably resulting from natural physiological processes. Nickel exposure produced a clear increase (an average of 1-2 per field of vision) in leukocyte blastic forms, the increase lasting until day 14 . This evidences the response of haemopoietic regenerative mechanisms. An identical reaction was described by Waluga and Fils (1971) in carp exposed to ammonium water, and by Waluga (1975) during a prolonged exposure to phenol in carp bream, Abramis brama, at a low temperature. Hypochromic anaemia and blood cell cytolysis during acute carp branchionecrosis were described by Sopińska (1985). Blood smears obtained after cadmium and nickel injections showed a reduction in the total lymphocyte count, including small and active lymphocytes, occurring 6 and 24 hours after injections, accompanied by increased counts of pseudoeosinophiles and monocytes after 6 and 24 hours. Erythrocytes present in the blood smears of intoxicated fish were observed to change their size and shape. Orecka-Grabda (1986) reported similar changes in the haematology of European eel, Anguilla anguilla, the changes being dominated by hypochromic anaemia with aniso- and poikilocytosis. The blood of the carp examined in this study showed the presence of numerous nucleated erythrocytes as well as increased contribution of young forms in the circulating blood. Similar changes were reported as occurring during sublethal phenol exposure of rainbow trout, "Salmo gairdneri" (= Oncorhynchus mykiss) (cf. Własow 1985). The mounts examined showed granulocyte vacuolisation to occur until day 14 after injections of both cadmium and nickel. A similar response of carp was observed by Sobecka (1985) in her study on the effects of environmental factors on haematological parameters and in the research on nickel exposure of the wels catfish, Silurus glanis. The peripheral blood smears of cadmium- and nickel-exposed carp showed vacuolised granulocytes. According to Begeman and Rasteter (1979), granulocytes produce vacuoles most probably as a result of oxygen disorders, the vacuoles being filled with a proteinaceous substance. Degenerative changes in granulocyte nuclei are interpreted as an effect of chemicals on the haemopoietic tissue, primarily kidneys and spleen in carp. The lymphocyte count was observed to drop 6 hours after cadmium and nickel injections. Williams et al. (1990) explained the reduction in the lymphocyte count by disintegration of immature lymphocytes in the haemopoietic organs as a result of cellular membrane damage. According to those authors, such process may be dependent on the zinc content, zinc being indispensable for $\mathrm{T}$ lymphocytes to form. The lymphocyte count reduction is accompanied by an increase in the monocyte level, which was observed in the nickelexposed carp at the final stage of the experiment. The changes in the haemoglobin content and haematocrit in the cadmium- and nickel-injected carp were most probably caused by an increase in the number of disintegrating erythrocytes, which in turn points to a disturbance in the oxygen budget. Similar changes in haematological parameters were reported by Waluga and Fils (1971) in their study of ammonium water effects on fish. Williams et al. (1990) found anaemia to be accompanied by reduction in haemoglobin oxygen saturation, hence the oxygen undersaturation of the entire body, which resulted in reduced oxygen pressure in the blood vessels.

\section{CONCLUSIONS}

1. Single intraperitoneal injections of sublethal doses of cadmium and nickel produced disintegration of carp erythrocytes and disturbed the metabolism and haemopoietic processes.

2. The leukocyte and lymphocyte counts were observed to decrease, compared with those of the control, 6 hours after cadmium and nickel injections.

3. Nickel injection resulted in the erythrocyte count being reduced, compared to the control and the cadmium-injected fish.

4. The haemoglobin content decreased after cadmium exposure, while increasing after nickel injection.

5. Detoxification resulted in a total elimination of haemopoietic disorders; the haematological parameters reverted to the physiological control, which took 14 and 30 days in the fish exposed to nickel and cadmium, respectively.

\section{ACKNOWLEDGEMENTS}

This study has been financially supported by the State Committee for Scientific Research (KBN) (grant No. 3 PO4E 030 22).

\section{REFERENCES}

Allen P., 1993. Effects of acute exposure to cadmium (II) chloride and lead (II) chloride on the hematological profile of Oreochromis aureus (Steindachner). Comparative Biochemistry and Physiology C 105: 213-217.

Areechon N., Plumb J.A., 1990. Sublethal effect of cadmium administration on the biliary excretion of $\mathrm{Cu}$ and $\mathrm{Zn}$ and tissue disposition of the metals. Environmental Research 26: 95-105.

Begeman H., Rasteter J., 1979. Atlas of clinical haematology. Springer-Verlag, Berlin.

Bomski H., 1995. Podstawowe laboratoryjne badania hematologiczne. [Basic laboratory techniques in haematology.] PZWL, Warszawa. (In Polish.)

Brucka-Jastrzębska E., Protasowicki M., 2004. Elimination dynamics of cadmium, administered by a single intraperitoneal injection in common carp Cyprinus carpio L. Acta Ichthyologica et Piscatoria 34 (2): 167-179.

Buczek J., Deptuła W., Gliński Z., Jarosz J., Stosik M., Wernicki A., 2000. Immunologia porównawcza i rozwojowa zwierząt. [Comparative and developmental animal immunology.] PWN, Warszawa. (In Polish.)

Francis-Floyd R., 1992. Environmental diseases of catfishes. pp. 506-510. In: Stoskopf M.K. (Ed.) Fish medicine. W.B. Saunders, Philadelphia. 
Haux C., Larsson A., 1984. Long-term sublethal physiological effects on rainbow trout, Salmo gairdneri, during exposure to cadmium and after subsequent recovery. Aquatic Toxicology 5: 129-142.

Houston A.H., Keen J.E., 1984. Cadmium inhibition of erythropoiesis in goldfish, Carassius auratus. Canadian Journal Fisheries and Aquatic Science 41: 1829-1834.

Jezierska B., Witeska M., 2001. Metal toxicity to fish. Wydawnictwo Akademii Podlaskiej, Siedlce.

Lusková V., 1997. Annual cycles and normal values of hematological parameters in fishes. Acta Scientiarum Naturalium Brno 31 (5): 1-70.

Morsy G., Protasowicki M., 1990. Cadmium bioaccumulation and its effects on some hematological and histological aspects in carp, Cyprinus carpio L., at selected temperature. Acta Ichthyologica et Piscatoria 20 (1): 105-116.

Nikinmaa M., Huestis W., 1984. Adrenergic swelling of nucleated erythrocytes: cellular mechanisms in a bird, domestic goose and two teleosts, striped bass and rainbow trout. Journal Experimental Biology 113: 215-224.

Orecka-Grabda T., 1986. Hematological, clinical and anatomical pathology of the European eel (Anguilla anguilla (L.)) form polluted waters of northwestern Poland. Acta Ichthyologica et Piscatoria 16 (1): 107-127.

Paláčková J., Pravdá D., Fasaic K., Čelechovská O., 1992. Sublethal physiological effects of cadmium on carp (Cyprinus carpio L.) fingerlings. EIFAC/XVII/92/Symp. E7. Lugano, Switzerland.

Pawelski S., Maj S., 1987. Normy i kliniczna interpretacja badań diagnostycznych w medycynie wewnętrznej. [Standards and clinical interpretation of diagnostic assays in internal medicine.] PZWL, Warszawa. (In Polish.)

Reddy P.M., Bashamohideen M.D., 1989. Fenvalerate and cypermethrin induced changes in the haematological parameters of Cyprinus carpio. Acta Hydrochimica et Hydrobiologica 17: 101-107.

Ruparelia S., Verma Y., Saiyed S., 1990. Effect of cadmium on blood of tilapia, Oreochromis mossambicus (Peters), during prolonged exposure. Bulletin of Environment Contamination and Toxicology 45: 305-312.

Saxena M.P., Gopal K., Jones W., Ray, P.K., 1992. Immune responses to Aeromonas hydrophila in catfish (Heteropneustis fossilis) exposed to cadmium and hexachlorocyclohexane. Bulletin of Environment Contamination and Toxicology 48: 194-201.

Seńczuk W., 1999. Toksykologia. Wydanie III. [Toxicology. Third edition.] PZWL, Warszawa. (In Polish.)

Singh N.N., Srivastava A.K., Srivastava A.K., 1992. Blood dyscrasia in the freshwater Indian catfish Heteropneustes fossilis after acute exposure to a sublethal concentration of propoxur. Acta Hydrobiologica 34: 189-195.

Sobecka E., 1985. Wpływ podwyższonej temperatury na wybrane parametry krwi obwodowej karpi Cyprinus carpio L. [Effects of increased temperature on selected parameters of the peripheral blood in carp Cyprinus carpio L.] Zeszyty Naukowe Akademi Rolniczej w Szczecinie; Rybactwo Morskie i Technologia Żywności 15 (113): 3-11. (In Polish.)

Sobecka E., 2001. Changes in the iron level in the organs and tissues of wels catfish, Silurus glanis L. caused by nickel. Acta Ichthyologica et Piscatoria 31 (2): 127-143.
Sopińska A., 1985. Effect of physiological factors, stress, and disease on hematologic parameters of carp, with a particular reference to the leukocyte patterns. III. Changes in blood accompanying branchionecrosis and bothriocephalosis. Acta Ichthyologica et Piscatoria 15 (2): 141-170.

Svobodová Z., Pravdá D., Paláčková J., 1986. Jednotné metody hematologického vyšetřování ryb. [Uniform methods of haematological studies on fish.] Výzkumný ústav rybářský a hydrobiologický ve Vodňanech. (In Czech.)

Svobodová Z., Vykusová B., Máchová J., 1994. The effects of pollutants on selected haematological and biochemical parameters in fish. pp. 39-52 In: Müller R., Lloyd R., (eds.) Sublethal and chronic effects of pollutants on freshwater fish. Fishing News Books, London.

Svobodová Z., Groch L., Flajšhans M., Vykusová B., Máchová J., 1997. The effect of longterm therapeutic bath of malachite green on common carp (Cyprinus carpio L.). Acta Veterinaria Brno 66: 111-117.

Srivastava A., K., Sahai I., 1987. Effects of loading density on carbohydrate metabolism and haematology in the Indian freshwater catfish, Heteropneustes fossilis. Aquaculture 66: 275-286.

Thomas M.B, Thomas W., Hornstein T.M., Hedman S.C., 1999. Seasonal leukocyte and erythrocyte counts in fathead minnows. Journal of Fish Biology 54: 1116-1121.

Tomaszewski J., 1997. Diagnostyka laboratoryjna. [Laboratory diagnostics.] PZWL, Warszawa.

Waluga D., Fils J., 1971. Zmiany we krwi obwodowej karpia (Cyprinus carpio Linnaeus, 1758.) pod wpływem wody amoniakalnej. [Changes in the peripheral blood of carp (Cyprinus carpio Linnaeus, 1758.) under influence of ammonia water.] Roczniki Nauk Rolniczych H 93 (2): 87-94.

Waluga D., 1975. Wpływ długotrwałego oddziaływania fenolu w niskiej koncentracji na leszcze - Abramis brama (L.). [Effects of long-term exposure to low concentrations of phenol in bream, Abramis brama (L.).] Zeszyty Naukowe Akademii Rolniczo-Technicznej w Olsztynie, Ochrona Wód i Rybactwo Śródlądowe 4: 35-78. (In Polish.)

Williams W.J., Beutler E., Erslev A.J., Lichtman M.A., 1990. Hematology. McGraw-Hill Publication, New York.

Witeska M., 1998. Changes in selected blood indices of common carp after acute exposure to cadmium. Acta Veterinaria Brno 67: 289-293.

Witeska M., Jezierska B., 1994. The effect of cadmium and lead on selected blood parameters of common carp. Archives of Polish Fisheries 2: 123-132.

Witeska M., Jezierska B., 1999. The effect of lead on blood of common carp in soft and hard water. pp. 285-290. In: Lovejoy D.A. (ed.) Heavy metals in the environment: an integrated approach. Conference presentations from the 1st International Conference "Metals in environment". Institute of Geology, Vilnius, Lithuania.

Własow T., 1985. The leukocyte system in rainbow trout, Salmo gairdneri Rich. affected by prolonged subacute phenol intoxication. Acta Ichthyologica et Piscatoria 15 (1): 83-92.

Received: 14 October 2004 Accepted: 4 April 2005 